\title{
Analysis of Acacia Wood Reinforced PLA/PHA Blend Composites
}

\begin{abstract}
MUHAMMAD KHUSAIRY BIN BAKRI, ELAMMARAN J AYAMANI*, SOON KOK HENG, AKSHAY KAKAR
Faculty of Engineering, Computing and Science, Swinburne University of Technology Sarawak Campus, Jalan Simpang Tiga, 93550, Kuching, Sarawak, Malaysia

This research focuses on the analysis of acacia wood reinforced PLA/PHA blend composites. Acacia wood was processed into small chip particles, which were mixed with pure PLA, pure PHA and PLA/PHA blend. The wood was treated using acetic acid and sodium bicarbonate. It was then compressed into sheet film. The micrograph shows that the PLA and PHA mixture create an interlocking continuous structure and the addition of wood strengthens interlocking between PLA and PHA. Mixtures of this blend also reduce bubble and crack, and create new properties superior than the earlier properties of existing PHA and PLA.
\end{abstract}

Keywords: hybrid, polymer, natural, bio-composites, wood

A few years ago, research studies were extensively conducted based on bio-composites on biodegradable polymer. However, the fabrication has started to slack due to its highly expensive production and it is paused due to limited technologies. As due to an intense search for alternatives to find replacement for petroleum-derived based polymer, the price of biodegradable polymer started to fall down in prices. However, it is still considered more expensive than the petroleum-derived based polymer. Furthermore, the continually increasing threat of overabundant plastic waste is becoming a huge problem as it impacted the environment as well as overfilled the landfills $[1,2]$. Thus, blending a few types of biopolymers on an extensive scale can help increase the biopolymer utilization and reduce costs and energy. It can also create a big turnover in the polymer industry, as it has a good life cycle for start and brings about a positive environmental impact from its production. Thus, it is best to create better biopolymer that can blend properly to fulfill the industry and product technical specification, especially to reduce the cost and create a better ratio in price-quality.

Poly lactic acid (PLA) is produced from simple glucose, sucrose, lactose, and maltose sugar extracted from the fermentation of corn, potato, cane, beet or cheese [3]. It is considered as a linear aliphatic polyester thermoplastic, which can be applied and used in biomedical surgical apparatus, particleboard, carpet, tiles, cloths and etc. The PLA is known to have good mechanical properties which reported by few researcher $[4,5]$. The tailoring work of PLA properties with fiber were also seen in a few of the researches $[6,7]$. Several researches show the compatibility of PLA blends with some other polymer such as poly (butyl acrylate), acrylonitrile-butadiene-styrene, poly ( $\varepsilon$-caprolactone) [8]. It shows that there is a good interaction and adhesion between fiber and matrix, which directly shows increasing in the mechanical properties. Polyhydroxyalkaonates (PHA) is a generically polyester polymer produced from bacterial fermentation of lipids and sugar. These polyesters are obtained due to the energy reserves and carbon storage in bacteria, especially in those Azotobacter chroocoum, Bacillus megaterium, Ralstonia eutropha. Thus, this will create a wide range of mechanical properties to PHA. It is considered as a semicrystalline structure depending on the range of temperature used and chemical composition it had.

Gerard and Budtova [9] and Schreck and Hillmyer [10] showed that PHA and PLA blend are not homogenous polymers and create new properties. Furthermore, blending
PLA and poly (hydroxybutyrate-co-hydroxyvalerate) (PHBV) can manipulate the ductility and brittleness of the biopolymer blend. Thus, this shows that the changes in the microstructure of semi-crystalline and amorphous structure of PHA and PLA blend can be changed by changing in the composition of PHA and PLA blends. By adding a 10 wt $\%$ of PHA to PLA, in improving the elongation of polymer blend of PHA significantly [11]. Improvements in the properties of natural fiber were seen as addition, due to reinforced of sisal and coir fiber [12,13]. Furthermore, chemical modification for both sisal and oil palm fibers increase the interfacial adhesions which show improvement in mechanical properties of it. Few researchers also found out that the absorption and stress relaxation were also seen with reference to chemical modification and fiber loading [14-17].

Thus, this work will present the results of acacia wood chip particles with hybrid PLA/PHA blend bio-composites. A few thin sheet films of samples were prepared; pure PLA, pure PHA, pure PLA/PHA, and untreated and treated wood PLA/PHA. The pros and cons that influence the properties of bio-composites will also be discussed. The recorded data was then compared theoretically and experimentally to give a full scope behavior of it.

\section{Experimental part \\ Methodology \\ Wood preparation}

The acacia wood sawdust was processed and turned it into small particles by using chipping machine provided by the Sarawak Forestry Department (SFD), Kuching, Sarawak. The acacia wood was obtained locally as part of forest re-plantation program in Malaysia generally and Sarawak specifically. Leguminous tree species, Acacia mangium are one of the subfamily Mimosoideae. It has a density range of $420-483 \mathrm{~kg} / \mathrm{m}^{3}$ (in green soaked volume) and $500-600 \mathrm{~kg} / \mathrm{m}^{3}$ (in dry condition) [18-22]. Naturally grown acacia wood has a specific gravity (SG) of 0.56 , while the re-plantation grown acacia wood has a lower SG of 0.40-0.45 [23]. However, in Borneo, the SG can specifically be obtained around $0.43-0.47$ for 6 years old acacia wood [24].

The acacia wood chip particles were then submerged and soaked for $24 \mathrm{~h}$ inside 1.5 of acetic acid solution. The acetic acid solution is obtained from Anita Food Industry Sdn. Bhd. Under the product name Cap Padi. It has $94 \%$ of $\mathrm{H}_{2} \mathrm{O}, 5 \%$ of $\mathrm{CH}_{3} \mathrm{COOH}$ and $1 \%$ of $\mathrm{NaCl}$. After that, $90 \mathrm{gm}$ of sodium bicarbonate, $\mathrm{NaCO}_{3}$ (baking pow der) were poured

\footnotetext{
*email: elammaranj@gmail.com
} 
into the soaked acacia wood chip particles for $24 \mathrm{~h}$. The sodium bicarbonate was supplied by Ee Syn Corporation Sdn. Bhd. The reaction between both acetic acid solution and sodium bicarbonate creates a reaction as follows:

$$
\mathrm{Na}_{2} \mathrm{CO}_{3}+2 \mathrm{CH}_{3} \mathrm{COOH} \rightarrow 2 \mathrm{CH}_{3} \mathrm{COONa}+\mathrm{H}_{2} \mathrm{O}+\mathrm{CO}_{2}
$$

The reaction causes neutralization between two different chemical reactions $(p H)$. Table 1 shows the properties of each chemical used. The acacia wood chip particles were filtered and rinsed using distilled water to neutralize the remaining chemical attached to the acacia wood chip particles. Lastly, it was dried inside an open ventilated oven under temperature of $80^{\circ} \mathrm{C}$ for $24 \mathrm{~h}$. Figure 1 shows the process of raw acacia wood sawdust into untreated and treated acacia wood sawdustchip particles.

\section{Hybrid Composites Preparation} alkanoates (PHA) (by a ratio of 1:1). Few samples were prepared: pure PLA, pure PHA, pure PLA/PHA, and mixture was added with $5 w t \%, 10 w t \%, 15 w t \%$, and $20 w t \%$ acacia wood chip particles. Sheet thin films of hybrid composites with thickness approximately $1 \mathrm{~mm}$ were made by using hot press machine.

The two plates were waxed before filled in with the mixture of composite ingredients. The releasing wax contained carnaubas are used and it is to prevent the sample from stick and stuck within the two plates when removing the samples out from the mould. The mixture of polymer and wood sawdust were then poured into the mould and compressed by using 30-ton hydraulic hot press machine with model code LS-22071 equipped by Lotus Scientific (Malaysia) Sdn. Bhd. under a pressure of 6.89 $\mathrm{MPa}$ at $150^{\circ} \mathrm{C}$ for $3-5 \mathrm{~min}$. The moulds were then quenched in water under room temperature $24 \pm 1^{\circ} \mathrm{C}$ for curing purposes.

\section{Light/Optical Microscopic Test}

Samples of thin sheet film were tested by using Eclipse $3 \times 2$ LV140 light/optical industrial microscope model equipped by Nikon (J apan) Corporation. The tests were run and evaluated according to ASTM E2015-04 [26].
The poly lactic acid (PLA) was mixed with polyhydroxyuntreated and treated wood PLA/PHA. The polymer

\section{Results and discussions}

Theoretically, when two or more different or identical polymer particles were heated, it will start to expand in size, when there is an increase in temperature [27]. As two or more polymer particles were close to each other due to compression or pressure during the hotcompression molding technique, the polymer particles tend to combine together. The combination of polymer particles will create one big formation, as it is attracted and pulled together due to compression or pressure. Similar or identical polymer will combine and become one bigger formation like those small bases of its polymer, while different or dissimilar polymer will create an interlock of bigger formation of two or more different or dissimilar polymer base.

The addition of fiber or wood as reinforced materials will strengthen the formation of two or more different or identical molecule or particles in polymer blends. According to Lourerio et al. [28] and Yu et al. [29], the adhesion properties were depending on the content of PHA and PLA. Whereas the content will have determined the structure formation it created. Figure 2 shows the process for (a) similar or identical molecule or particle [27], (b) different or dissimilar (non-identical) molecule or particles, and (c) addition of fiber or wood as reinforced material. Implosion happens when sudden change in hot to cool temperature as the material quenched in water. Quenching caused shrink formation of the materials that indirectly closer the pack between the two or more molecules or particles and its structure. Figure 3, shows the formation that created when two polymer blend together with fiber/wood.

Acacia woods have unique small porous structure, opening, membranes, pits and an intricately layered wall thattends to allow polymer to enter in which create a unique interlock between two or more molecules or particles [30]. Chemical treatment causes the wood chip sawdust particles to be preserved and increase in pore size, structure, opening, pits, and membranes, which is due to the removal intricate layer wall of cellulose, hemicellulose, lignin, wax, and oil structure. Thus, this will increase the absorption rate of polymer into the wood structure due to hydrophilic and hydrophobic interaction.

Figure 4 shows the light/optical micrographs of pure PLA, pure PHA, pure PLA/PHA, and untreated and treated acacia wood PLA/PHA composites. Figure 4 (a) and (b) shows the internal minor crack and bubble structure in

Table 1

PROPERTIES OF CHEMICALS AND ITS REACTIONS

\begin{tabular}{|c|c|c|c|}
\hline Product & $\begin{array}{c}\text { Acetic Acid Solution } \\
\text { (Synthetic White Vinegar) }\end{array}$ & $\begin{array}{c}\text { Sodium Bicarbonate } \\
\text { (Baking Powder) }\end{array}$ & $\begin{array}{c}\text { Acetic Acid Solution (Synthetic White } \\
\text { Vinegar) + Sodium Bicarbonate (Baking } \\
\text { Powder) }\end{array}$ \\
\hline pH Level & 2.55 (Acidic Base) & 8.50 (Alkaline Base) & 7.09 (Neutral Base) \\
\hline Voltage & $265.0 \mathrm{mV}$ & $-88.5 \mathrm{mV}$ & $-5 \mathrm{mV}$ \\
\hline $\begin{array}{c}\text { Temperature and } \\
\text { Pressure }\end{array}$ & \multicolumn{2}{|l|}{ Standard temperature and pressure (STP), 100kPa (1 bar), 298.1K (25 ${ }^{\circ} \mathrm{C}, 77^{\circ} \mathrm{K}$ ) (ASTM E41-92) [25] } \\
\hline
\end{tabular}

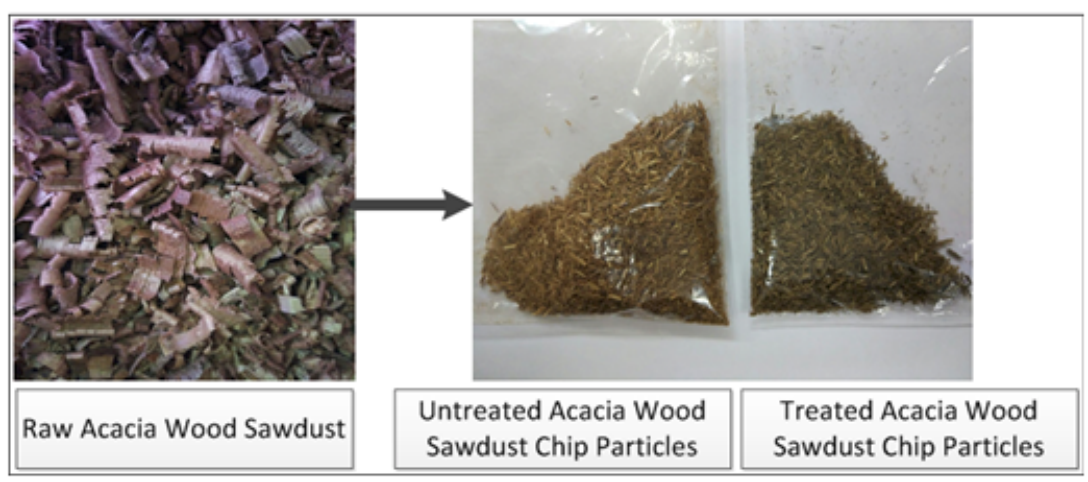

Fig. 1. Raw sawdust processed into untreated and treated acacia wood sawdust chip particles 


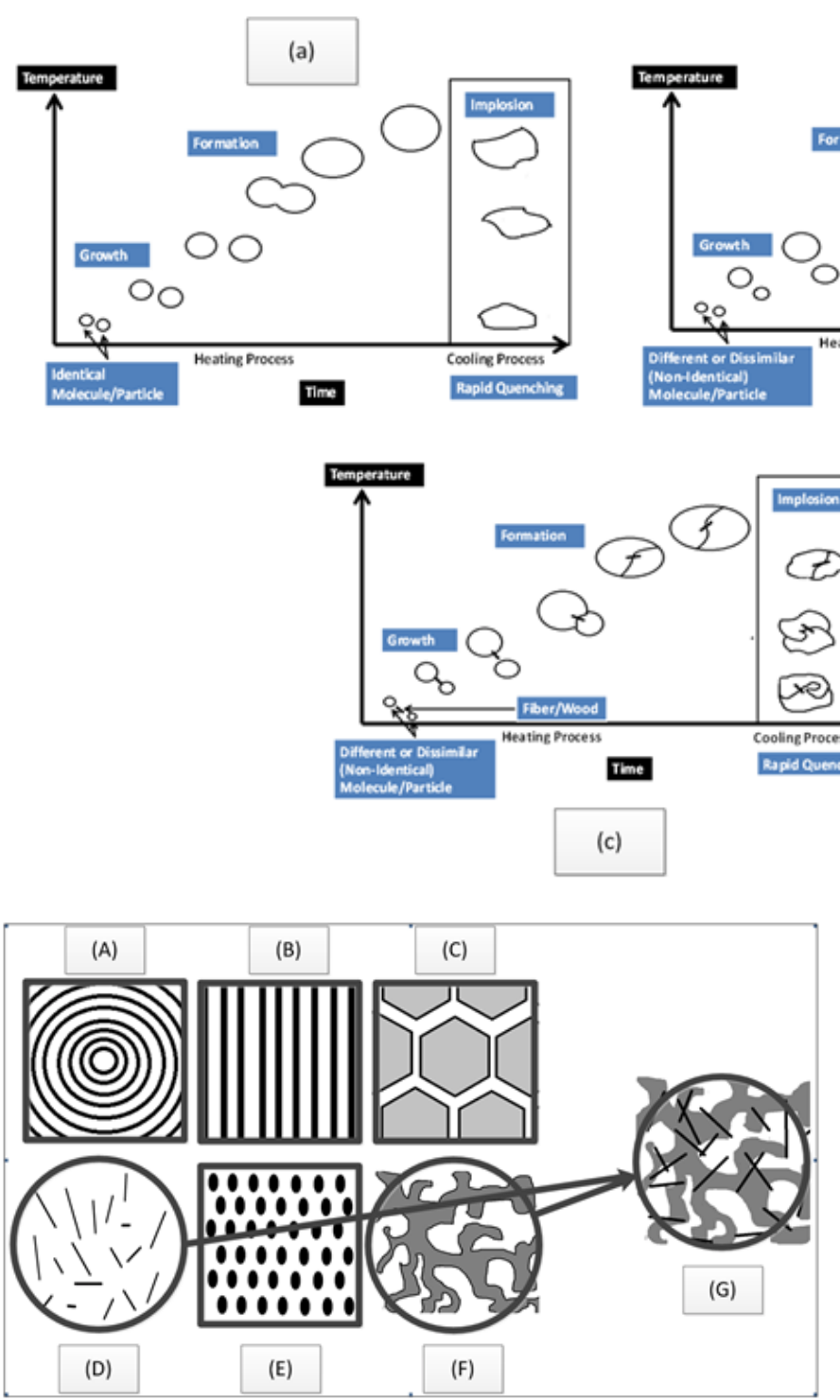

Fig. 3. Examples of structural configurations of hybrids composite:

(a) concentric cylindrical shells, (b) sandwich, (c) honeycomb,

(d) chopped fibers, (e) particulate, (f) amorphous/crystalline blend, and (g) mixture of (d) and (f) [27]

PLA. The bubble structure may be due to overheat (higher temperature above than optimal melting point that encourage creation of bubble), while the crack usually due to indirectly permissibility force during removal of composite sample. As PHA has better stiffness structure, as can be seen in figure 4 (c), it has less bubbles and crack problems. By combining both PLA and PHA, itcreates and optimal structures which create better interlock structures which have optimum strength and flexural properties, as shown in Figure 4 (d). The addition of acacia wood sawdust chip particles creates an interlocking structure between two polymer blend in the composites. However, the untreated one have disadvantages than the treated one which cause poor surface adhesion as can be seen in figure 4 (e) and better adhesion in figure 4 (f). The treatment also creates surface roughness on the acacia wood sawdust
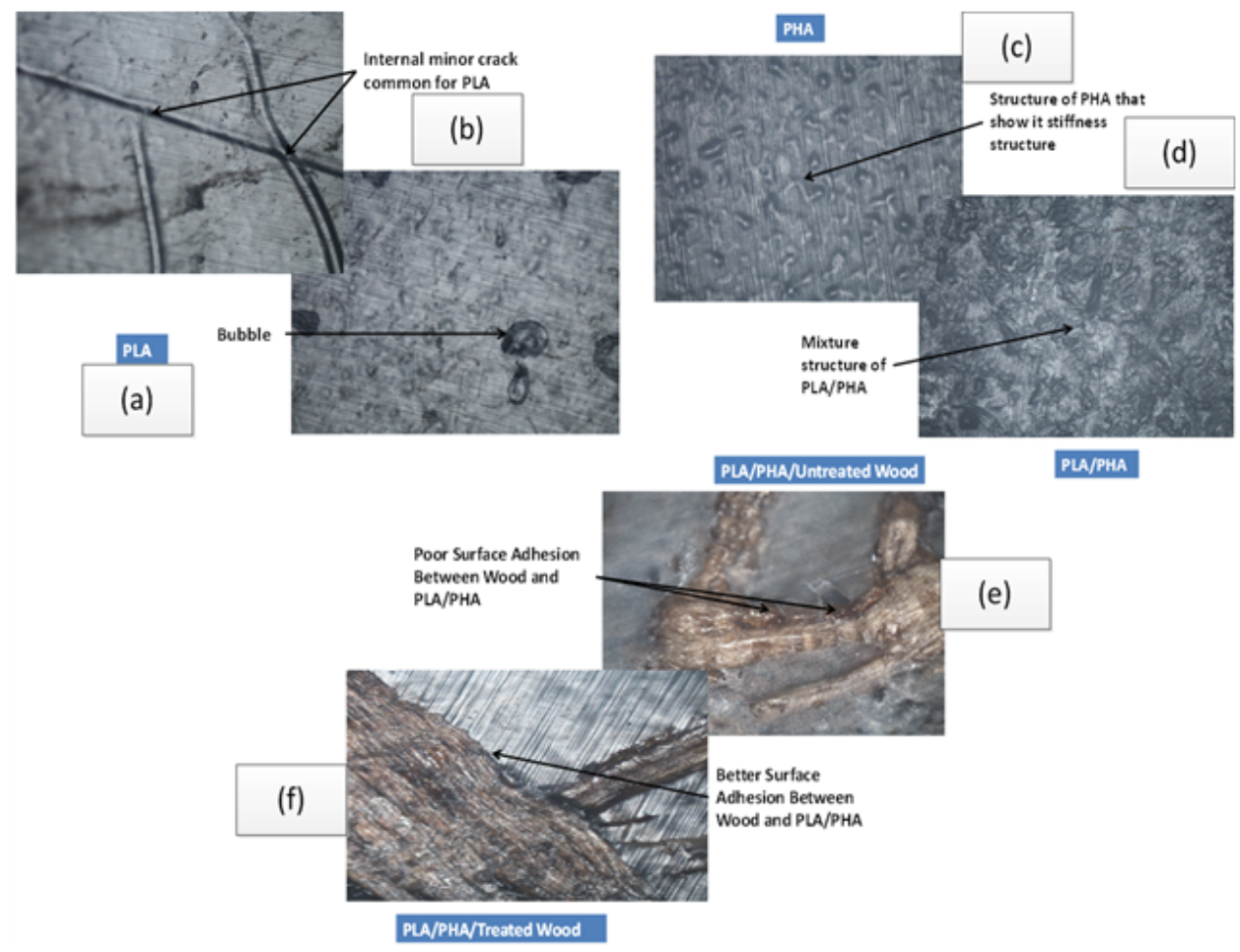

Fig. 4. light/optical micrographs for (a) bubble structure in PLA, (b) internal crack in PLA, (c) PHA stiffness structure, (d) mixture of PLA and PLA structure, (e) untreated acacia wood chip sawdust particles, and (f) treated acacia wood chip sawdust particles 
chip particles. Gerard and Budtova [9] shows similar results in their optical micrograph, where PLA/PHBV shows cocontinuous structure that bind together.

\section{Conclusions}

In essence, the mixture of two differenttypes of polymer particles, PLA and PHA, create an interlocking continuous structure that creates one new big formation of polymer blends, which gives new properties to the polymer by reducing both disadvantages in their own identical properties like bubble and crack. Addition of acacia wood sawdust chip particles, create a secure interlock between two types of polymer blend, while the chemical treatment increases the preservation rate and adhesion in the biocomposites.

\section{References}

1.STACHUREK I., Zeszyty Naukowe Wyiszej Szko³y Zarz dzania Ochron ${ }^{1}$ Pracy W Katowicach, 8, 2012, p. 74;

2.NANDA M.R., Macromol. Mater. Eng., 296, 2001, p. 719;

3. AURAS R., HARTE B., SELKE S., Macromol. Biosci., 4, 2004, p. 835; 4. BAJPAI P.K., SINGH I., MADAAN J., J. of Thermoplast. Compos. Mater., 27, 2014, p. 52;

5. BAJPAI P.K., SINGH I., MADAAN J., J. Reinforc. Plast. Compos., 31, 2012, p. 1712;

6.MOFOKENG J.P., LUYT A.S., TABI T., KOVACS J., J. Thermoplast. Compos. Mater., 25, 2012, p. 927;

7. AVELlA M., BUZAROVSKA A., ERRICO M.E., GENTILE G., GROZDANOV A., Polym. Compos. Mater., 2, 2009, p. 911;

8. SIMOES C.L., VIANA J.C., CUNHA A.M., J. Appl. Polym. Sci., 112, 2009, p. 345;

9.GERARD T., BUDTOVA T., Int. Conf. on Biograd. and Biobased Polym., 1, 2011, p. 1;

10.SCHRECK K.M., HILLMYER M.A., J. Biotech., 3, 2007, p. 287;

11. NODA I., SATKOWSKI M.M., DOWREY A.E., MARCOTT C., Macromol. Biosci., 4, 2004, p. 269;
12. HASEENA A.P., DASAN K.P., NAMITHA R., UNNIKRISHNA G., THOMAS

S.A., Compos. Interfaces, 11, nr. 7, 2004, p. 489;

13. HASEENA A.P., DASAN K.P., UNNIKRISHNAN G., THOMAS S., Prog. Rubber. Plast. Re., 21, nr. 3, 2005, p. 155;

14. JACOB M., VARUGHESE K.T., THOMAS S., Biomacromolecules, $\mathbf{6}$, nr. 6, 2005, p. 2969;

15. JACOB M., FRANCIS B., THOMAS S., VARUGHESE K.T., Polym. Compos., 27, nr. 6, 2006, p. 671;

16. JACOB M., JOSE S., THOMAS S., VARUGHESE K.T., J Reinforc. Plast. Compos., 25, nr. 18, 2006, p. 1903;

17. J ACOB M., VARUGHESE K.T., THOMAS S., J. Mater. Sci., 41, nr. 17, 2006, p. 5538;

18. LOGAN A.F., BALODIS V., Malaysian Forester, 45, 1982, p. 217;

19. PEH T.B., KHOO K.C., LEE T.W., Malaysian Forester, 45, 1982, p. 404;

20. PEH T.B., KHOO K.C., Malaysian Forester, 47, 1984, p. 285;

21. WANG Q., SASAKI H., RAZALI A.K., Wood Res. and Technical, 25, 1989, p. 45;

22. RAZALI A.K., KUO H.S., Proceedings of Symposium on Recent Development in Tree Plantations of Humid/Subhumid Tropics of Asia, 1, 1983, p. 685;

23.*** National Research Council, Natural Academic Press, Washington DC, 1983.

24. SINING U., Thesis, Pertanian University, Malaysia.

25.*** ASTM E41-92, Terminology Relating to Conditioning, ASTM International, West Conshohocken, PA, 2009.

26. *** ASTM E2015-04. Standard guide for preparing of plastics and polymeric specimens for microstructural examination. ASTM International, West Conshohocken, PA, 2009.

27. AVILA-ORTA C.A., et.al., InTech, Rijeka, 2013, p. 1;

28. LOURERIO N.C., ESTEVESJ .L., VIANA J .C., GHOSH S., J. Thermoplas. Compos. Mater., 28, 2015, p. 195;

29. YU L., DEAN K., LI L., Prog. Polym. Sci., 31, 2006, p. 576;

30. DHAMODARAN T.K., CHACKO K.C., KFRI Research Report, 174, 1999, p. 1.

$\overline{\text { Manuscript received: } 15.09 .2018}$ 